\title{
ASSESSMENT OF THE INTENTION TO CONSUME FARMED FISH USING THE THEORY OF PLANNED BEHAVIOUR - SCALE VALIDATION
}

\author{
Dina Lončarić \\ PhD, Associate Professor, University of Rijeka, Faculty of Tourism and Hospitality Management, \\ Primorska 46, 51410 Opatija, Croatia; e-mail: dinal@fthm.hr

\section{Elena Dujmić} \\ MSc, University of Rijeka, Faculty of Tourism and Hospitality Management, \\ Primorska 46, 51410 Opatija, Croatia; e-mail: elenad@fthm.hr

\section{Greta Krešić} \\ PhD, Full Professor, University of Rijeka, Faculty of Tourism and Hospitality Management, \\ Primorska 46, 51410 Opatija, Croatia; e-mail: gretak@fthm.hr
}

\begin{abstract}
SUMMARY
One-quarter of fish consumed in Europe comes from aquaculture and research has shown that consumers have a greater preference for wild fish in comparison with farmed ones. As with other food choices, consumer decisions regarding farmed fish are a complex process involving multiple factors. The main objective of this study is to develop and validate a questionnaire that will measure consumer intentions in the consumption of farmed fish using the theory of planned behaviour (TPB) as a theoretical framework. Based on the TPB model, the study also investigates the relationships between attitudes, subjective norms, perceived behavioural control and intention to consume farmed fish. Data collection was performed through an online survey and a total of 118 valid questionnaires were analysed. Based on tests performed, results indicate that the tested scale for measuring TPB constructs is valid and reliable. Alpha coefficients for intention, attitudes, subjective norms and perceived behavioural control were $0.898,0.857,0.748$ and 0.953 , respectively. Variables in the model explain $40 \%$ of the variation in farmed fish consumption intentions. Regression analysis confirmed that attitudes and subjective norms significantly influence intention to consume farmed fish, with the subjective norms being the strongest predictor, while perceived behavioural control does not have a significant impact on behavioural intention.
\end{abstract}

Key words: Aquaculture, consumer, farmed fish, theory of planned behaviour 


\section{INTRODUCTION}

Fish is widely recognised as an essential part of a healthy and balanced diet because of its highly valuable protein content and provision of essential nutrients such as iodine, selenium, calcium, and vitamins A and D (EFSA, 2014). Due to its nutritional value and anti-inflammatory effect, fish is associated with positive health benefits in many pathological conditions such as cardiovascular diseases, obesity, metabolic syndrome, mental health, and cancer (Bork et al., 2020; Jayedi, ShabBidar, 2020; Natto et al., 2019).

Global food fish consumption has more than doubled in the last sixty years, from $9.0 \mathrm{~kg}$ per capita (in 1961) to $20.5 \mathrm{~kg}$ per capita in 2018 and it is expected to continue to grow (FAO, 2020). The underlying factors behind the growing demand for fish are rapid population growth, rising incomes, urbanisation, and increased awareness of the health benefits of fish, facilitated by advancements in the processing and packaging industry and distribution channels (Béné et al., 2015; OECD/FAO, 2018). Since capture fisheries reached a plateau in the late 1980s, with negligible opportunity to expand, aquaculture has become the future of the seafood industry, filling in the demand-supply gap and will continue to play an important role in global food security and nutrition (Anderson et al., 2017; Kobayashi et al., 2015; Martin, 2017). From its beginnings, it is the fastest-growing food production system in the world and currently contributes to more than half of the fish available for human consumption. This share will continue to increase further (FAO, 2020).

However, in Europe, only one-quarter of fish consumed comes from aquaculture (EUMOFA, 2019) which may be due to consumers' greater preference for wild fishery products than farmed ones (reviewed by Cantillo et al., 2020, Carlucci et al., 2015). Farmed fish is often perceived as inferior in terms of the overall quality or taste, health, nutritional value, and safety (Claret et al., 2014; López-Mas et al., 2021; Verbeke, Brunsø, 2005; Verbeke et al., 2007; Rickertsen et al., 2017). Hall and Amberg (2013) concluded in their research that such beliefs are negatively associated with the consumption of farmed fish. On the contrary, a recent study by López-Mas et al. (2021) suggests that positive perception of product does not necessarily lead to higher consumption, i.e. most of the participants preferred wild fish but consumed farmed fish more often. Thus, it becomes clear that along with other food choices, consumer decisions regarding farmed fish are a complex process involving multiple factors.

To the best of authors' knowledge, there is an insufficient number of papers investigating the intention of consumers to consume farmed fish. Therefore, the main objective of this study is to develop and validate a questionnaire that will measure consumers' intention to consume farmed fish, using the theory of planned behaviour as a theoretical framework. Based on the TPB model, the study also investigates the relationships between attitudes, subjective norms, perceived behavioural control and intention to consume farmed fish. In the following sections, the theoretical framework, research hypotheses, methodology and findings are described and discussed. Finally, the results of the research are discussed, and conclusions are drawn. 


\section{LITERATURE REVIEW AND THEORETICAL FRAMEWORK}

The theory of planned behaviour (TPB) is one of the socio-cognitive models most commonly employed to understand different human behaviours, proving suitable in explaining and predicting different food consumption decisions (Ajzen, 2015; McDermott et al., 2015). In the literature, much research can be found that uses the original, extended, or modified TPB model to explain the variance in fish consumption intention and behaviour. Some of these studies have even applied it in the context of a new (Olsen et al., 2008) or preferred type of fishery product (Siddique, 2012; Tomić et al., 2016). For others, it was a tool for observing differences in fish consumption behaviour before and after nutrition education intervention (Mahumudiono et al., 2020) or for measuring the success of an advertising campaign for fresh fish (Scholderer, Grunert, 2001). To the best of the authors' knowledge, there are not many studies $(\mathrm{Yi}, 2019)$ that have applied this theory to farmed fish. Therefore, this research should make a valuable contribution to the scarce scientific data.

\subsection{Theory of planned behaviour}

According to Ajzen (1991), behavioural intention is the immediate antecedent of any behaviour. The stronger a person's intention, i.e. the more motivated a person is, the more likely the behaviour will be performed. Intention is influenced by three independent constructs, namely attitudes, subjective norms, and perceived behavioural control. Attitudes are defined as a person's overall evaluation of certain behaviour as favourable or unfavourable and they are based on one's beliefs regarding the subject and the possible outcomes of the behaviour. The second antecedent of intention, subjective or social norms, refers to the perceived social pressure to perform or not perform the behaviour (Ajzen, 1991). Given the fact that people are social beings, they value the opinions of others who are important to them. More recently, it has been suggested that subjective norms should also consist of descriptive normative beliefs that are based on the observed actions of those social referents (Ajzen, 2015). An added construct to the previously established theory of reasoned action (TRA) (Fishbein, Ajzen, 1975) is perceived behavioural control, which can account for a major part of the variance in behaviour in combination with intentions. It refers to an individual's perception of the ease or difficulty to perform a certain behaviour and it is assumed to reflect past experiences as well as anticipated difficulties and obstacles. The TPB predicts that the more positive attitudes, greater subjective norms, and perceived behavioural control an individual has towards behaviour, the intention to perform such behaviour will be stronger (Ajzen, 1991).

Table 1 summarises the results of the studies in the domain of fish consumption. For a more precise overview, only those studies with original constructs or that have been expanded with additional ones are included. The table illustrates how good a predictor a particular construct is and to what extent the model explains the variance in intention. 
D. Lončarić, E. Dujmić, G. Krešic: Assessment of the intention to consume farmed fish using the theory... Zbornik Veleučilišta u Rijeci, Vol. 9 (2021), No. 1, pp. 1-17

Table 1. Sample TPB studies on fish consumption intention

\begin{tabular}{|c|c|c|c|c|c|}
\hline \multirow{2}{*}{ Study (Country) } & \multirow{2}{*}{ Theory } & \multicolumn{4}{|c|}{ Regression coefficients } \\
\hline & & ATT & SN & PBC & $\mathbf{R}^{2}$ \\
\hline \multirow{2}{*}{$\begin{array}{l}\text { Verbeke, Vackier, } 2005 \\
\text { (Belgium) }\end{array}$} & TPB & 0.21 & 0.18 & 0.27 & 0.31 \\
\hline & extended TPB* & $0.06^{\mathrm{ns}}$ & 0.12 & $-0.01^{\text {ns }}$ & 0.52 \\
\hline $\begin{array}{l}\text { Olsen et al., } 2008 \text { (Norway, } \\
\text { Spain) }\end{array}$ & TPB & 0.21 & 0.12 & 0.43 & 0.46 \\
\hline Tuu et al., 2008 (Vietnam) & extended TPB* & 0.33 & 0.12 & 0.16 & 0.31 \\
\hline Aghamolaei et al., 2012 (Iran) & TPB & 0.42 & 0.12 & 0.28 & 0.54 \\
\hline Siddique, 2012 (Bangladesh) & extended TPB* & 0.19 & 0.36 & $-0.03^{\text {ns }}$ & 0.54 \\
\hline $\begin{array}{l}\text { Thong, Olsen, } 2012 \\
\text { (Vietnam) }\end{array}$ & TPB & 0.43 & 0.35 & $0.13^{\text {ns }}$ & 0.35 \\
\hline \multirow{2}{*}{$\begin{array}{l}\text { Mitterer-Daltoe et al., 2013a } \\
\text { (Brazil) }\end{array}$} & TPB & 0.25 & 0.42 & 0.21 & 0.33 \\
\hline & extended TPB* & 0.15 & $0.10^{\text {ns }}$ & $0^{\text {ns }}$ & 0.57 \\
\hline Tomić et al., 2016 (Croatia) & extended TPB* & 0.40 & 0.22 & 0.13 & 0.40 \\
\hline $\begin{array}{l}\text { Fiandari et al., } 2019 \\
\text { (Indonesia) }\end{array}$ & extended TPB* & 0.66 & $0.10^{\text {ns }}$ & 0.37 & N/A \\
\hline Yi, 2019 (South Korea) & TPB & 0.32 & 0.41 & 0.32 & N/A \\
\hline \multirow{2}{*}{ Huang et al., 2020 (China) } & TPB & 0.27 & 0.25 & $0.14^{\mathrm{ns}}$ & 0.28 \\
\hline & extended TPB* & $0.07^{\mathrm{ns}}$ & $0.06^{\mathrm{ns}}$ & 0.19 & 0.58 \\
\hline
\end{tabular}

ATT = attitude towards the behaviour, $\mathrm{SN}=$ subjective norm, $\mathrm{PBC}=$ perceived behavioural control, INT= intention; *= other constructs also contribute to intention; $n s=$ not significant; N/A= not available

Source: Authors

Studies conducted among Belgian, Iranian and Brazilian consumers suggest that attitudes, subjective norms and perceived behavioural control significantly predicted intention to eat fish (Aghamolaei et al., 2012; Mitterer-Daltoe et al., 2013a; Verbeke, Vackier, 2005). In line with these are the results obtained by Olsen et al. (2008) when examining the intention to consume a new fish product (i.e. fish burger) in a multi-group context. Furthermore, all constructs proved to be significant factors in investigating consumers' purchase of sustainably produced aquaculture products certified by the Aquaculture Stewardship Council (ASC) (Yi, 2019). However, perceived behavioural control was not a significant predictor of intention in the case of Vietnamese and Chinese fish consumers (Huang et al., 2020; Thong, Olsen, 2012). In the extended TPB model, introducing perceived need and/or habit as additional regressors weakened the impact of at least two constructs but at the same time increased the explained variance of behavioural intention (Mitterer-Daltoe et al., 2013a; Huang et al., 2020; Verbeke, Vackier, 2005). Tuu et al. (2008) distinguished social and descriptive norms as direct antecedents of intention, with both having a significantly positive effect on the intention to consume fish (note: in Table 1, the regression coefficient of social norms has been 
presented). Additional constructs in repetitive (perceived value) and fresh (health involvement, moral obligation) fish consumption have insignificant and low correlation, respectively, with behavioural intention (Fiandari et al., 2019; Tomić et al., 2016). The findings of the extended TPB model proposed by Siddique (2012) suggest that attitudes, norms and procedural knowledge are the key determinants of intention, whereas perceived behavioural control, price and cost had no significant effect on the intention to consume dry fish. On top of all that, a few studies with the extended TPB model measured perceived behavioural control only through past experience, which provided the best explanation of the intention to eat fish (Higuchi et al., 2017; Mitterer-Daltoe et al., 2013b). Variables related to facilitating conditions were not used in the structural model as they were rejected by the confirmatory analysis (Mitterer-Daltoe et al., 2013b). Lastly, Honkanen and Young (2015) replaced perceived behavioural control with the perception of consumer effectiveness as a possible predictor of intention towards buying sustainable seafood, but it proved to be insignificant while attitude, subjective and personal norms were positively related.

\subsection{Research hypotheses}

Attitudes are generally the strongest predictor of food consumption intentions (Ajzen, 2015). In line with this, several studies confirm that positive attitudes towards fish consumption have the most significant effect on the intention to consume fish (Aghamolaei et al., 2012; Fiandari et al., 2019; Thong, Olsen, 2012; Tomić et al., 2015; Tuu et al., 2008). However, introducing habit as a separate regressor in the extended TPB model weakens the impact of attitudes on behavioural intention (Huang et al., 2020; Verbeke, Vackier, 2005). Further, Thong and Olsen (2012) found in their study that fish taste, texture, and appearance, used as indicators of quality, have the highest impact on attitude and together with price and negative effect (smell and bones) explain $60 \%$ of the variation in attitude. The taste and healthy image of fish proved to be the strongest influence on the intention to consume fresh fish among Croatian consumers (Tomić et al., 2016). Hence, the following hypothesis is:

H1: Positive attitudes towards the consumption of farmed fish have a positive impact on the intention to consume farmed fish.

Subjective norms have often been argued as the poorest predictor of intention within most studies of TPB (Ajzen, 1991), as well as having the weakest association within discrete food choice (McDermott et al., 2015). However, along with attitudes they have been important determinants in the intention to eat fish (Mitterer-Daltoe et al., 2013a; Thong, Olsen, 2012). Verbeke and Vackier (2005) concluded that, in the subjective norms, the importance of persons in the direct social environment is much greater than that of institutions. The social pressure factor proved to be the strongest in the case of purchasing ASC-certified aquaculture products in Korea (Yi, 2019), highlighting sustainable consumption as a desired behaviour in that country. The proposed hypothesis follows:

H2: Subjective norms towards the consumption of farmed fish have a positive impact on the intention to consume farmed fish. 
Even though the inclusion of the perceived behavioural control construct improved the earlier theory of reasoned action (Fishbein, Ajzen, 1975) by improving the ability to predict intention and behaviour, it has received mixed results in the domain of fish consumption. Several studies suggest it has a positive but weak or completely insignificant relationship with intention (Huang et al., 2020; Thong, Olsen, 2012; Tomić et al., 2016; Tuu et al., 2008). Verbeke and Vackier (2005) found perceived behavioural control as the most important predictor in the intention to consume fish. However, when habit is added as a separate regressor, perceived behavioural control becomes insignificant (Mitterer-Daltoe et al., 2013a). When it comes to the intention of consuming a new fish product, perceived behavioural control has the most influence (Olsen et al., 2008). Therefore, the following hypothesis is proposed:

H3: Perceived behavioural control towards the consumption of farmed fish has a positive impact on the intention to consume farmed fish.

\section{RESEARCH METHODOLOGY}

The objectives of the research are: 1) to design and verify the validity and reliability of the questionnaire for measuring attitudes, subjective norms, perceived behavioural control and intentions towards farmed fish consumption and 2) to determine the impact of attitudes, subjective norms and perceived behavioural control on farmed fish consumption intentions. In order to achieve these goals, a survey questionnaire was designed and tested on data collected by empirical research.

\subsection{Questionnaire and measurement scales}

Empirical data were collected by the survey method. Scales from the literature (Tomić et al., 2016) were used to measure attitudes, subjective norms and perceived behavioural control. Additionally, data on the socio-demographic profile of the respondents were collected. Altogether, the research tool consisted of 16 statements, all adapted to the research objectives, namely to behavioural intention towards farmed fish. Attitudes towards farmed fish were measured with five statements, while four statements were used to measure subjective norms. To measure perceived behavioural control, we used three statements, which were reverse coded. To measure the intention to consume farmed fish, we formulated four new statements related to the purchase of farmed fish in the future and the consumption of farmed fish in a catering facility. All items were measured on 5-point Likert-like scales, ranging from 1 ("strongly disagree") to 5 ("strongly agree").

Since the scales for measuring TPB constructs were translated and adapted to the subject of the research, and new statements were added, it was necessary to check the validity and reliability of the questionnaire.

\subsection{Data collection and sample}

The survey was answered by persons in charge of purchasing food in the household. The research collected data from the residents of coastal and continental Croatia according to the National 
Classification of Territorial Units for Statistics (DZS, 2012). The questionnaire was posted online (Google form), and respondents were contacted by e-mail. The snowball method was used to collect data in July 2019. A total of 123 valid questionnaires were collected.

At the beginning of the survey, a filter question was asked: Do you consume fishery products? Only five respondents (4\%) stated that they do not consume fishery products, while $96 \%$ of respondents stated that they do. As the most common reasons for not consuming fish, the respondents stated that they do not have the habit (3 respondents), that they do not like fish or do not like the smell/ taste, and that the offering is not satisfactory ( 2 respondents). One respondent stated that he is allergic to fish. These five subjects were excluded from further analysis, so the analysis is based on the responses of 118 subjects. The socio-demographic description of the study sample is shown in Table 2.

Table 2. Socio-demographic structure of the sample $(\mathrm{N}=118)$

\begin{tabular}{|c|c|c|}
\hline \multicolumn{2}{|c|}{ SOCIO-DEMOGRAPHIC VARIABLES } & \multirow{2}{*}{$\begin{array}{c}\% \\
79.7 \\
20.3 \\
\end{array}$} \\
\hline Sex & $\begin{array}{l}\text { Female } \\
\text { Male }\end{array}$ & \\
\hline Age & $\begin{array}{c}19-25 \\
26-35 \\
36-50 \\
51-65 \\
>65\end{array}$ & $\begin{array}{c}5.1 \\
29.6 \\
44.1 \\
19.5 \\
1.7\end{array}$ \\
\hline Education level & $\begin{array}{l}\text { Secondary school } \\
\text { Bachelor } \\
\text { Master or higher }\end{array}$ & $\begin{array}{c}5.1 \\
4.2 \\
90.7\end{array}$ \\
\hline Number of household members & $\begin{array}{l}1 \\
2 \\
3 \\
4 \\
5 \\
6\end{array}$ & $\begin{array}{c}4.2 \\
23.7 \\
30.5 \\
33.9 \\
5.1 \\
2.6\end{array}$ \\
\hline Number of household members under the age of 18 & $\begin{array}{l}0 \\
1 \\
2 \\
3\end{array}$ & $\begin{array}{l}51.7 \\
27.1 \\
18.7 \\
2.5\end{array}$ \\
\hline Employment status & $\begin{array}{l}\text { Employed full time } \\
\text { Part-time employee } \\
\text { Unemployed } \\
\text { Retiree } \\
\text { Student }\end{array}$ & $\begin{array}{c}89.0 \\
0.8 \\
0.9 \\
4.2 \\
5.1\end{array}$ \\
\hline Residence & $\begin{array}{c}\text { Continental Croatia } \\
\text { Coastal Croatia }\end{array}$ & $\begin{array}{l}61.9 \\
38.1\end{array}$ \\
\hline
\end{tabular}


D. Lončarić, E. Dujmić, G. Krešic: Assessment of the intention to consume farmed fish using the theory... Zbornik Veleučilišta u Rijeci, Vol. 9 (2021), No. 1, pp. 1-17

\begin{tabular}{|l|c|c|}
\hline & Less than 2000 & 5.9 \\
Size of the settlement (number of inhabitants) & $2000-4999$ & 5.9 \\
& $5000-9999$ & 4.3 \\
& $10000-99999$ & 18.7 \\
& $100000-199999$ & 39.8 \\
& 200000 and more & 25.4 \\
\hline Average household income per month (HRK)* & Less than 5000 & 1.7 \\
& $5001-10000$ & 17.0 \\
& $10001-15000$ & 33.9 \\
& $15001-20000$ & 20.3 \\
& 20001 and more & 25.4 \\
\hline
\end{tabular}

$1 \mathrm{HRK} \approx 0.13$ euros

Source: Authors

The final study sample consisted of 118 participants ( $79.7 \%$ female and $20.3 \%$ male). Almost half of the study participants (44.1\%) belong to the age range group of 36-50 years, followed by the age range group of $26-35$ years (29.7\%). Only two participants are older than 65 years. About $90 \%$ of the participants hold a university degree. One-third of participants live in households with four members, while a slightly smaller percentage live in a 3-member household (30.5\%). Half of the participants have no children, while one and two children were reported by $27.1 \%$ and $18.5 \%$ of the participants, respectively. Almost $90 \%$ of the study participants are fully employed, $4.2 \%$ are still students, and $5.1 \%$ are retired. Monthly income by household of $33.9 \%$ of participants is in the range of $10001-15000 \mathrm{HRK}$, while $45.7 \%$ reported income higher than $15001 \mathrm{HRK}$. Of the total number of respondents, $61.9 \%$ come from coastal, and 38.1\% from continental Croatia. Only 19\% of participants live in settlements with less than 10000 inhabitants, while the rest (83.8\%) live in settlements with more than 10001 inhabitants.

\subsection{Data analysis}

Data analysis was performed using quantitative methods. Descriptive statistics were used to describe the sample and the mean values and standard deviations of items included in the measurement scale, while validation of measurement scales was performed using multivariate statistics. Exploratory factor analysis was applied to determine the dimensionality of the constructs, while the internal consistency coefficient Cronbach's alpha was used to assess the reliability of the scales for measuring the constructs. The data gathered were analysed using the IBM SPSS Statistics 26 program (www.ibm.com).

\section{FINDINGS}

\section{1 Descriptive analysis}

Initially, descriptive analysis of the items included in the scale was conducted. The TPB constructs with their mean values and standard deviations are presented in Table 3. 
Table 3. Descriptive statistics $(\mathrm{N}=118)$

\begin{tabular}{|c|c|c|c|c|c|}
\hline Code & Item & Min & Max & Mean & Std. Deviation \\
\hline ATT_1 & I like to eat farmed fish. & 1 & 5 & 3.19 & 0.81 \\
\hline ATT_2 & Eating farmed fish is healthy. & 1 & 5 & 3.41 & 0.71 \\
\hline ATT_3 & I feel good after eating farmed fish. & 1 & 5 & 3.41 & 0.67 \\
\hline ATT_4 & Farmed fish has a good taste. & 1 & 5 & 3.60 & 0.64 \\
\hline ATT_5 & I am very satisfied when farmed fish is on the menu. & 1 & 5 & 2.94 & 0.74 \\
\hline SN_1 & My family thinks that I should eat farmed fish. & 1 & 5 & 2.66 & 0.85 \\
\hline SN_2 & My friends think that I should eat farmed fish. & 1 & 5 & 2.58 & 0.80 \\
\hline SN_3 & My family eats farmed fish. & 1 & 5 & 3.33 & 0.93 \\
\hline SN_4 & My friends eat farmed fish. & 1 & 5 & 3.26 & 0.67 \\
\hline PBC_1 & $\begin{array}{l}\text { I do not find it difficult to judge the quality of farmed } \\
\text { fish. }\end{array}$ & 1 & 5 & 3.13 & 0.89 \\
\hline PBC_2 & $\begin{array}{l}\text { When I buy farmed fish, the chance to make a bad } \\
\text { choice is small. }\end{array}$ & 1 & 4 & 2.53 & 0.70 \\
\hline PBC_3 & $\begin{array}{l}\text { When I buy farmed fish, I am sure that I make a good } \\
\text { choice. }\end{array}$ & 1 & 4 & 2.63 & 0.82 \\
\hline INT_1 & In the future, I plan to buy farmed fish. & 1 & 5 & 3.49 & 0.95 \\
\hline INT_2 & $\begin{array}{l}\text { In the future, I plan to consume farmed fish in a catering } \\
\text { facility. }\end{array}$ & 1 & 5 & 3.18 & 0.92 \\
\hline INT_3 & I will certainly buy farmed fish. & 1 & 5 & 3.43 & 0.91 \\
\hline INT_4 & I will certainly consume farmed fish in a catering facility. & 1 & 5 & 3.23 & 0.93 \\
\hline
\end{tabular}

$\mathrm{ATT}=$ attitude towards the behaviour, $\mathrm{SN}=$ subjective norm, $\mathrm{PBC}=$ perceived behavioural control, INT= intention

Source: Authors

Respondents had moderately positive attitudes towards farmed fish consumption (mean values were between 3.19 and 3.60) and the intention to consume farmed fish (mean values were in the 3.18-3.49 range). The only exception is satisfaction when farmed fish is on the menu, with slightly negative results $(2.94 \pm 0.74)$, while most of the respondents agreed with the fact that farmed fish has

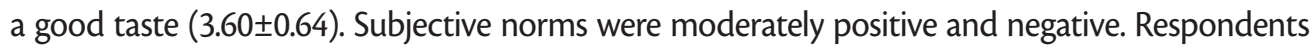
disagreed that their family and friends think they should consume farmed fish, while at the same time they believe that they do consume it. Furthermore, none of the respondents firmly believe that the purchase of farmed fish is a good choice, and most of them disagreed on that.

\section{2 Validation of the measurement scales}

After generating items which reflect the domain of the desired constructs and forming the measurement scales, the validation of the scales should be performed. The first step in the validation of the formed measuring scale for measuring TPB constructs is to determine the content validity of the scale. Experts with experience in scientific research in the field of nutrition and marketing determined the content validity of all constructs. They used a qualitative assessment to judge whether the content of the statements corresponds to the subject of the research. They 
also assessed the clarity and unambiguity of the statements, and understanding and readability of the questionnaire. All constructs were found to be well covered by the questions included in the measurement scales.

In the second step, the psychometric characteristics of the scale were assessed using the data collected. In order to determine the dimensionality of the TPB constructs measurement scale and reduce a large number of manifest variables to a smaller number of factors while maintaining the greatest possible variance of the initial results, explorative factor analysis was performed on the scale items. The Kaiser-Meyer-Olkin coefficient $(0.842)$ and Bartlett's sphericity test $\left(\chi_{(120)}^{2}=\right.$ 1281,$68 ; p<0.001$ ) showed that the correlation matrix was suitable for factor analysis according to the recommendations of Tabachnik and Fidell (2007). This analysis was performed using principal component analysis with varimax rotation. The criteria for the number of factors extracted and variables retained were based on eigenvalues and percentage of variance explained. Factors with eigenvalues greater than one and a solution with at least $60 \%$ of the total variance explained were considered acceptable (Hair, 2014). To ensure convergent validity, variables with a factor loading greater than 0.50 were retained considering the sample size (Hair, 2014). To guarantee discriminant validity, we accepted the rule that variables should load significantly only on one factor.

The reliability of the measurement scales was determined by applying the internal consistency coefficient Cronbach alpha. Acceptable values of Cronbach's alpha coefficients are higher than the threshold value of 0.70 (Nunnaly, Bernstein, 1994).

The factor analysis carried out with regard to the above criteria resulted in a solution that extracted four factors explaining $78.11 \%$ of the variance (Table 4). A total of three variables were excluded due to the high loading on more than one factor. One statement referred to attitudes ("I am very satisfied when farmed fish is on the menu.") and two items, to subjective norms ("My family eats farmed fish." and "My friends eat farmed fish.").

Table 4. Factor loadings and alpha coefficients for the TPB constructs

\begin{tabular}{|l|c|c|c|c|c|c|}
\hline & \multicolumn{4}{|c|}{ Component } & \multirow{2}{*}{ Total variance explained (\%) } & Alpha coefficient \\
\cline { 2 - 5 } & 1 & 2 & 3 & 4 & & \\
\hline INT_1 & 0.724 & & & & & \multirow{2}{*}{43.85} \\
\hline INT_2 & 0.852 & & & & & 0.898 \\
\hline INT_3 & 0.750 & & & & & \\
\hline INT_4 & 0.888 & & & & & \multirow{2}{*}{0.857} \\
\hline ATT_1 & & 0.763 & & & & \\
\hline ATT_2 & & 0.819 & & & & \\
\hline ATT_3 & & 0.843 & & & & \\
\hline ATT_4 & & 0.683 & & & & \\
\hline
\end{tabular}




\begin{tabular}{|l|l|l|l|l|c|c|}
\hline PBC_1 & & & 0.765 & & & \multirow{2}{*}{10.94} \\
PBC_2 & & & 0.801 & & 0.748 \\
\hline PBC_3 & & & 0.830 & & & 0.953 \\
\hline SN_1 & & & & 0.922 & 9.31 & 0.931 \\
\hline SN_2 & & & & 0.931 & \\
\hline
\end{tabular}

$\mathrm{ATT}=$ attitude towards the behaviour, $\mathrm{SN}=$ subjective norm, $\mathrm{PBC}=$ perceived behavioural control, INT= intention

Source: Authors

The reliability of the measurement scales was determined by applying the internal consistency coefficient Cronbach alpha. Alpha values for extracted factors range from 0.748 to 0.953 , which is above the acceptability limit of 0.70 .

Based on the tests performed and the results obtained, we can conclude that the scale for measuring attitudes, subjective norms, perceived behavioural control and the intention to consume farmed fish is valid and reliable.

After validation of the measurement scales, hypothesis testing was performed using the multiple linear regression method (Table 5).

Table 5. Multiple regression analysis for variables predicting intention to consume farmed fish

\begin{tabular}{|l|c|c|c|c|c|}
\hline Independent variables & b & SE & Beta & T & Sig. \\
\hline Constant & 0.337 & 1,558 & & 0.216 & 0.829 \\
\hline Attitudes & 0.461 & 0.156 & 0.229 & 2.959 & 0.004 \\
\hline Subjective norms & 0.664 & 0.110 & 0.485 & 6.042 & 0.000 \\
\hline Perceived behavioural control & 0.159 & 0.124 & 0.097 & 1.281 & 0.203 \\
\hline $\mathrm{R}^{2}$ & 0.419 & & & & \\
Adjusted R & 0.404 & & & & \\
Standard error & 2.506 & & & & \\
F ratio & 27.454 & & & & \\
Significance & 0.000 & & & & \\
\hline
\end{tabular}

Dependent variable: Intention to consume farmed fish

Source: Authors

Regression analysis was applied to test whether the intention to consume farmed fish can be explained by attitudes towards farmed fish, subjective norms and perceived behavioural control. Prior to regression analysis, four new variables were formed as linear composites of manifest variables, derived from the results of exploratory factor analysis. 
The results of regression analysis are statistically significant $(\mathrm{F}=27.454, \mathrm{p}=0.000)$ and show that the variables in the model explain $40.4 \%$ of the variation in farmed fish consumption intention. The analysis confirmed that attitudes $(\beta=0.229, p=0.004)$ and subjective norms $(\beta=0.485, p=0.000)$ significantly influence intention to consume farmed fish. Contrary to this, perceived behavioural control does not have a significant impact on behavioural intention $(\beta=0.097, p=0.203)$. Based on this evidence, it can be concluded that hypotheses $\mathrm{H} 1$ and $\mathrm{H} 2$ have been confirmed, while hypothesis $\mathrm{H} 3$ is rejected.

To better understand the relationship of attitudes and subjective norms with behavioural intention, a correlation analysis of manifest variables was performed applying the Pearson correlation coefficient. The results show that, among attitudes, the variables "I like to eat farmed fish" and "Farmed fish has a good taste" have the highest correlation with behavioural intention, with $r=0.568, p=0.000$ and $r=0.531, p=0.000$, respectively. The lowest correlation observed is between the statement "Eating farmed fish is healthy" and the intention to consume farmed fish ( $r=0.399$, $p=0.000$ ). When it comes to subjective norms, the associations between behavioural intention and the statements "My family thinks that I should eat farmed fish" ( $r=0.413, p=0.000)$ and "My friends think that I should eat farmed fish" ( $r=0.429, \mathrm{p}=0.000)$ are similar.

\section{DISCUSSION}

The present study uses TPB to explain the intention to consume farmed fish in a random sample of Croatian consumers. Results indicate that the model explains $40 \%$ of the variance in behavioural intentions, which corroborates with the reviewed studies in Table 1.

As hypothesised, subjective norms (i.e. social norms), being the strongest predictor of intention, have a positive impact on the intention to consume farmed fish, which is consistent with the findings in a similar study focused on the intention to purchase sustainably produced aquaculture products (Yi, 2019). Mitterer-Daltoe et al. (2013a) also identified subjective norms as the most influential construct within the original TPB model on fish consumption in Brazil, while Thong and Olsen (2012) reported social pressure being a significant and strong predictor in Vietnam, although it followed after attitude. The results are in contradiction with a number of studies that have identified subjective norms as the least influential construct in overall behaviour as well as in nutrition- and health-related behaviours (Ajzen, 1991; Armitage, Conner, 2001; McDermott et al., 2015, McEachan et al., 2011 Riebl et al., 2015). Armitage and Conner (2001) suggested that a possible explanation of the weak predictive power of subjective norms lies in the fact that they are typically measured by a single item. Multiple-item measures had significantly stronger correlations with intention. In the present study, only social norms related to family and friends were included, both having a similar association with intention. Verbeke and Vackier (2005) explained that social pressure to consume fish mainly comes from direct social environments rather than external ones (government, food industry, advertising). Furthermore, in line with the latest suggestions, descriptive norms were also included as part of the subjective norms but were discarded in the confirmatory factor analysis. 
Despite not being the most important antecedent of intention in this study, attitudes as an overall evaluation have a strong and significant impact on intention, with a result similar to those in previous studies (Mitterer-Daltoe et al., 2013a; Olsen et al., 2008; Verbeke, Vackier, 2005), suggesting that an increase in favourable attitudes will be accompanied by an increase in the intention to consume farmed fish. Consumers who like to eat farmed fish and enjoy its taste had a stronger intention to consume farmed fish. Sensory liking of fish as the strongest determinant for the intention to consume fish was also identified in other studies (Mitterer-Daltoe et al., 2013a; Tomić et al., 2016; Verbeke, Vackier, 2005). However, contrary to the findings of Tomić et al. (2016), healthy image was the least appreciated characteristic in farmed fish consumption. Mitterer-Daltoe et al. (2013a) came to an interesting finding when they examined the effects of attitudes on behaviour. Despite having a positive attitude, people did not eat fish, although they did have the intention.

The intention to eat farmed fish is determined by attitudes and subjective norms but is not significantly affected by perceived behavioural control. Although not in line with the TPB postulate, it is no exception among studies on fish consumption (Huang et al., 2020; Siddique, 2012; Thong, Olsen, 2012). Furthermore, in the extended TPB models, including habit as a separate construct renders insignificant the impact of perceived behavioural control (Mitterer-Daltoe et al., 2013a; Verbeke, Vackier, 2005). Possible explanations were provided by Thong and Olsen (2012). First, it could be that the intention to consume farmed fish is under volitional control as TRA assumed, meaning that intention to eat farmed fish is driven significantly by the attitude towards farmed fish and social pressure of family and friends. Secondly, if perceived control is a significant predictor of behaviour, but does not affect intention, it suggests that farmed fish consumption is not likely under volitional control and that there is probably a difference between perceived control and actual control. Since the present study does not investigate behavioural constructs, the explanation remains unknown. It is yet to be examined to what extent perceived behavioural control influences the consumption of farmed fish. The existing evidence of fish consumption behaviour indicates that perceived behavioural control is a significant predictor in most studies, but not more important than intention (Aghamolaei et al., 2012; Fiandari et al., 2019; Thong, Olsen, 2012; Tomić et al., Tuu et al., 2008; Verbeke, Vackier, 2005).

\section{CONCLUSION}

In conclusion, it can be pointed out that the scale for measuring attitudes, subjective norms, perceived behavioural control and the intention to consume farmed fish is valid and reliable. The strength of this study lies in the fact that a reliable and valid tool for measuring intention to consume farmed fish has been established and tested among Croatian consumers. Additionally, the intention to consume farmed fish is determined by attitudes and subjective norms but not by perceived behaviour control.

At the end, it is necessary to point out the limitations of this study. One of the shortcomings is the small and purposive sample on which the research was conducted, so future research should be conducted on a more extensive and representative sample. Furthermore, consumer intention, rather than actual behaviour, was investigated. It is possible that the respondents gave socially desirable answers when they were asked about the intention to consume farmed fish. Therefore, 
future research should examine whether there is a relationship between intention and actual behaviour - consumption of farmed fish. In future research, the theory of planned behaviour can be extended using new constructs, as for example, consumer knowledge of farmed fish or others.

This work was performed within the project AdriaAquaNet - Enhancing Innovation and Sustainability in Adriatic Aquaculture, financed under the INTERREG V-A Italy - Croatia 2014 2020 programme. The financing of the work by the European Union is gratefully acknowledged.

\section{REFERENCES}

Aghamolaei, T., Tavafian, S. S., Madani, A. (2012) "Fish consumption in a sample of people in Bandar Abbas, Iran: application of the theory of planned behaviour", Archives of Iranian Medicine, 15(9), p. 545-548.

Ajzen, I. (1991) "The theory of planned behaviour", Organizational Behavior and Human Decision Processes, 50(2), p. 179-211. https://doi.org/10.1016/0749-5978(91)90020-T

Ajzen, I. (2015) "Consumer attitudes and behavior: the theory of planned behavior applied to food consumption decisions", Italian Review of Agricultural Economics, 70(2), p. 121-138. https://doi.org/10.13128/REA-18003

Armitage, C. J., Conner, M. (2001) "Efficacy of the Theory of Planned Behaviour: A meta-analytic review", British Journal of Social Psychology, 40, p. 471-499. https://doi.org/10.1348/014466601164939

Anderson, J. L. et al. (2017) "Aquaculture: Its Role in the Future of Food”, U: Schmitz, A., Kennedy, P. L., Schmitz, T. G. (ur.) World Agricultural Resources and Food Security (Frontiers of Economics and Globalization, Vol. 17). Bradford: Emerald Publishing Limited, p. 159-173. https://doi.org/10.1108/S1574-871520170000017011

Béné, C. et al. (2015) “Feeding 9 billion by 2050 - Putting fish back on the menu”, Food Security, 7, p. 261-274. https:// doi.org/10.1007/s12571-015-0427-z

Bork, C. S. et al. (2020) "Marine n -3 fatty acids and CVD: New insights from recent follow-up studies and clinical supplementation trials", Proceedings of the Nutrition Society, p. 1-7. https://doi.org/10.1017/S0029665120006886

Cantillo, J., Martín, J. C., Román, C. (2020) “Discrete choice experiments in the analysis of consumers' preferences for finfish products: A systematic literature review", Food Quality and Preference, 84, 103952. https://doi.org/10.1016/j. foodqual.2020.103952

Carlucci, D. et al. (2015) "Consumer purchasing behaviour towards fish and seafood products. Patterns and insights from a sample of international studies", Appetite, 84, p. 212-227. https://doi.org/10.1016/j.appet.2014.10.008

Claret, A. et al. (2014) "Consumer beliefs regarding farmed versus wild fish", Appetite, 79, p. 25-31. https://doi. org/10.1016/j.appet.2014.03.031

DZS (2012) Nacionalna klasifikacija prostornih jedinica za statistiku 2012. (NKPJS 2012.), Narodne novine, 96.

EFSA (2014) "Scientific Opinion on health benefits of seafood (fish and shellfish) consumption in relation to health risks associated with exposure to methylmercury", EFSA Journal, 12(7), 3761. https://doi.org/10.2903/j.efsa.2014.3761

EUMOFA (2019) The EU fish market - 2019 edition. Luxembourg: Publications Office of the European Union.

FAO (2020) The State of World Fisheries and Aquaculture 2020 - Sustainability in action. Rome: Food and Agriculture Organization of the United Nations. https://doi.org/10.4060/ca9229en

Fiandari, Y. R. et al. (2019) "Perceived value dimension in repetitive fish consumption in Indonesia by using an extended theory of planned behaviour", British Food Journal, 121(6), p. 1220-1235. https://doi.org/10.1108/BFJ-07-2018-0429

Fishbein, A., Ajzen, I. (1975) Belief, attitude, intention, and behavior: An introduction to theory and research, Reading, MA: Addison-Wesley. 
Hair, J. F. et al. (2014) Multivariate data analysis, 7th ed. Harlow: Pearson Education Limited

Hall, T. E., Amberg, S. M. (2013) “Factors influencing consumption of farmed seafood products in the Pacific northwest”, Appetite, 66, p. 1-9. https://doi.org/10.1016/j.appet.2013.02.012

Higuchi, A., Dávalos, J., Hernani-Merino, M. (2017) “Theory of planned behavior applied to fish consumption in modern Metropolitan Lima”, Food Science and Technology, 37(2), p. 202-208. http://dx.doi.org/10.1590/1678-457x.17516

Honkanen, P., Young, J. A. (2015) “What determines British consumers' motivation to buy sustainable seafood?”, British Food Journal, 117(4) p. 1289-1302. https://doi.org/10.1108/BFJ-06-2014-0199

Huang, J., Antonides, G., Nie, F. (2020) "Social-Psychological Factors in Food Consumption of Rural Residents: The Role of Perceived Need and Habit within the Theory of Planned Behavior", Nutrients, 12(4), 1203. https://doi.org/10.3390/ nu12041203

Jayedi, A., Shab-Bidar, S. (2020) "Fish Consumption and the Risk of Chronic Disease: An Umbrella Review of MetaAnalyses of Prospective Cohort Studies", Advances in Nutrition, 11(5), p. 1123-1133. https://doi.org/10.1093/ advances/nmaa029

Kobayashi, M. et al., (2015) "Fish to 2030: The Role and Opportunity for Aquaculture", Aquaculture Economics \& Management, 19(3), p. 282-300. http://dx.doi.org/10.1080/13657305.2015.994240

López-Mas et al., (2021) “Farmed or wild fish? Segmenting European consumers based on their beliefs”, Aquaculture, 532, 735992. https://doi.org/10.1016/j.aquaculture.2020.735992

Mahmudiono, T. et al. (2020) "Nutrition Education Intervention Increases Fish Consumption among School Children in Indonesia: Results from Behavioral Based Randomized Control Trial", International Journal of Environmental Research and Public Health, 17(19), 6970. https://doi.org/10.3390/ijerph17196970

Martin, C. (2017) “Not so many fish in the sea”, Current Biology, 27, p. 439-443. https://doi.org/10.1016/j.cub.2017.05.049.

McDermott, M. S. et al. (2015) "The theory of planned behaviour and discrete food choices: a systematic review and meta-analysis", International Journal of Behavioral Nutrition and Physical Activity, 12, 162. https://doi.org/10.1186/ s12966-015-0324-z

McEachan, R. R. C. et al. (2011) "Prospective prediction of health-related behaviours with the Theory of Planned Behaviour: a meta-analysis", Health Psychology Review, 5(2), p. 97-144. https://doi.org/10.1080/17437199.2010.5 21684

Mitterer-Daltoé, M. L. et al. (2013a) "Reasons Underlying Low Fish Consumption Where Availability Is Not an Issue. A Case Study in Brazil, One of the World's Largest Fish Producers", Journal of Sensory Studies, 28(3), p. 205-216. https:// doi.org/10.1111/joss.12037

Mitterer-Daltoé, M. L. et al. (2013b) "Structural equation modelling and word association as tools for a better understanding of low fish consumption" Food Research International, 52(1), p. 56-63. https://doi.org/10.1016/j. foodres.2013.02.048

Natto, Z. S. et al. (2019) "Omega-3 Fatty Acids Effects on Inflammatory Biomarkers and Lipid Profiles among Diabetic and Cardiovascular Disease Patients: A Systematic Review and Meta-Analysis", Scientific Reports, 9, 18867. https:// doi.org/10.1038/s41598-019-54535-x

Nunnally, J. C., Bernstein, I. H. (1994) Psychometric Theory, New York: McGraw-Hill, p. 265.

OECD/FAO (2018) OECD-FAO Agricultural Outlook 2018-2027. Paris: OECD Publishing, Rome: Food and Agriculture Organization of the United Nations. https://doi.org/10.1787/agr_outlook-2018-en

Olsen, S. O. et al. (2008) "Explaining intention to consume a new fish product: A cross-generational and cross-cultural comparison", Food Quality and Preference, 19(7), p. 618-627. https://doi.org/10.1016/j.foodqual.2008.04.007

Rickertsen, K. et al. (2017) "French Consumers' Attitudes and Preferences Toward Wild and Farmed Fish", Marine Resource Economics, 32(1), p. 59-81. https://doi.org/10.1086/689202 
Riebl, S. K. et al. (2015) "A systematic literature review and meta-analysis: The Theory of Planned Behavior's application to understand and predict nutrition-related behaviors in youth", Eating Behaviors, 18, p. 160-178. https://doi. org/10.1016/j.eatbeh.2015.05.016

Scholderer, J., Grunert, K. G. (2001) “Does generic advertising work? A systematic evaluation of the Danish campaign for fresh fish", AquacultureEconomics \& Management, 5(5-6), p.253-271. https://doi.org/10.1080/13657300109380293

Siddique, M. A. M. (2012) "Explaining the Role of Perceived Risk, Knowledge, Price, and Cost in Dry Fish Consumption Within the Theory of Planned Behavior", Journal of Global Marketing, 25(4), p. 181-201. https://doi.org/10.1080/0 8911762.2012.743203

Tabachnik B. G., Fidell L. S. (2007) Using Multivariate Statistics, 5th ed. Boston, MA: Pearson Education, p. 614

Thong, N. T., Olsen, S. O. (2012) "Attitude toward and Consumption of Fish in Vietnam", Journal of Food Products Marketing, 18(2), p. 79-95. https://doi.org/10.1080/10454446.2012.653778

Tomić, M., Matulić, D., Jelić, M. (2016) “What determines fresh fish consumption in Croatia?", Appetite, 106, p. 13-22. https://doi.org/10.1016/j.appet.2015.12.019

Tuu, H. H. et al. (2008) "The role of norms in explaining attitudes, intention and consumption of a common food (fish) in Vietnam", Appetite, 51(3), p. 546-551. https://doi.org/10.1016/j.appet.2008.04.007

Verbeke, W., Brunso, K. (2005) “Consumer awareness, perceptions and behaviour towards farmed versus wild fish" U: The economics of aquaculture with respect to fisheries, 95th EAAE Seminar. Civitavecchia (Rome): European Association of Agricultural Economists, p. 237-251. https://doi.org/10.22004/ag.econ.56075

Verbeke, W., Vackier, I. (2005) "Individual determinants of fish consumption: application of the theory of planned behaviour", Appetite, 44(1), p. 67-82. https://doi.org/10.1016/j.appet.2004.08.006

Verbeke, W. et al. (2007) "Consumer perception versus scientific evidence of farmed and wild fish: Exploratory insights from Belgium", Aquaculture International, 15(2), p. 121-136. https://doi.org/10.1007/s10499-007-9072-7

Yi, S. (2019) "Determinants of Consumers' Purchasing Behavior for Certified Aquaculture Products in South Korea", Sustainability, 11(14), 3840. https://doi.org/10.3390/su11143840 
Izvorni znanstveni rad

https://doi.org/10.31784/zvr.9.1.1

Datum primitka rada: 23. 11. 2020.

Datum prihvaćanja rada: 3. 2. 2021.

\title{
PROCJENA NAMJERE KONZUMACIJE RIBE IZ UZGOJA PRIMJENOM TEORIJE PLANIRANOG PONAŠANJA - VALIDACIJA SKALE
}

\author{
Dina Lončarić \\ Dr. sc., izvanredna profesorica, Sveučilište u Rijeci, Fakultet za menadžment u turizmu i ugostiteljstvu, \\ Primorska 46, 51410 Opatija, Hrvatska; e-mail: dinal@fthm.hr

\section{Elena Dujmić} \\ Mag. nutr., Sveučilište u Rijeci, Fakultet za menadžment u turizmu i ugostiteljstvu, \\ Primorska 46, 51410 Opatija, Hrvatska; e-mail: elenad@fthm.hr

\section{Greta Krešić} \\ Dr. sc., redovita profesorica, Sveučilište u Rijeci, Fakultet za menadžment u turizmu i ugostiteljstvu, \\ Primorska 46, 51410 Opatija, Hrvatska; e-mail: gretak@fthm.hr
}

\section{SAŽETAK}

Jedna četurtina ribe konzumirane u Europi potječe iz uzgoja (akvakulture). Istraživanja su međutim pokazala da potrošači ipak preferiraju ribu iz ulova u usporedbi sa ribom iz uzgoja. Kao i kod odabira ostalih vrsta hrane, potrošačke odluke vezane uz ribu iz uzgoja složen su proces koji uključuje više čimbenika. Glavni cilj ovog rada je razviti i validirati upitnik koji će mjeriti namjere potrošača da konzumiraju ribu iz uzgoja u okviru teorije planiranog ponašanja (TPP). Također, na temelju TPP modela istražen je odnos između stavova, subjektivnih normi, percipirane kontrole ponašanja i namjere konzumacije ribe iz uzgoja. Podaci su prikupljeni putem online ankete te je ukupno analizirano 118 valjanih upitnika. Dobiveni rezultati potvrđuju valjanost i pouzdanost testiranih ljestvica za mjerenje konstrukata u okviru TPP. Alfa koeficijenti za namjere, stavove, subjektivne norme i percipiranu kontrolu ponašanja iznosili su 0,898, 0,857, 0,748 te 0,953. Varijable u modelu objašnjavaju 40\% varijacija u namjerama konzumacije ribe iz uzgoja. Regresijska analiza potvrdila je da stavovi i subjektivne norme statistički značajno utječu na namjeru konzumacije ribe iz uzgoja, pri čemu su subjektivne norme najsnažniji prediktor, dok percipirana kontrola ponašanja nema statistički značajan utjecaj na namjeru ponašanja.

Ključne riječi: akvakultura, potrošač, uzgojena riba, teorija planiranog ponašanja 
